\title{
Blood Chemistry (Hematology) of Transfusion Dependent Beta Thalassemia Patients at Hyderabad and Adjoining Areas
}

\author{
Dildar Ali Solangi ${ }^{1,2}$, Naseem Aslam Channa ${ }^{2 *}$, Nasreen Memon ${ }^{1}$, Amna Yasin \\ Awan $^{2}$, Nadir Ali Shah ${ }^{1}$, Attaullah Ansari ${ }^{1}$ and Juma Khan Turk ${ }^{1}$ \\ ${ }^{1}$ Department of Zoology, University of Sindh, Jamshoro-76080, Pakistan. \\ ${ }^{2}$ Institute of Biochemistry, University of Sindh, Jamshoro-76080, Pakistan. \\ *Corresponding Author Email: nachanna2000@ gmail.com \\ Received 08 May 2018, Revised 21 June 2018, Accepted 25 June 2018
}

\begin{abstract}
Present study was carried out to analyze quantitatively the blood parameters of Transfusion Dependent Thalassemia (TDT) patients. A total number of seventy one $(n=71)$ TDT patients aged 04 to 26 years were selected from Fatimid foundation center, Hyderabad from June 2015 to May 2016 and eighty four $(n=84)$ control subjects (age, gender and locality matched persons with negative personal and family history of thalassemia) were included in this study. Blood sample of $5 \mathrm{~mL}$ was collected from each participant to analyze white blood cells (WBC); total leukocytes counts (TLC); red blood cells (RBC); mean corpuscular value (MCV); mean corpuscular hemoglobin $(\mathrm{MCH})$; mean corpuscular hemoglobin concentration (MCHC); hemoglobin (HB) and hematocrit (HCT). All the patients and control subjects were interviewed through a standard questionnaire specially developed to study their life style and dietary habits. The collected data from TDT patients and control subjects was statistically analyzed by using $p<0.05$ as statistically significant variation between two groups. Results revealed significantly decreased levels of HCT, $\mathrm{MCV}, \mathrm{MCH}$ and platelets in TDT patients as compared to control subjects. All TDT patients were frequently undergoing blood transfusion within the age groups.
\end{abstract}

Keywords: Thalassemia, Analysis, Hematology, Dietary habits, Hyderabad division.

\section{Introduction}

Thalassemia is a group of inherited disorders of hemoglobin, first reported independently from the United States and Italy [1]. About 250 million people carry defective gene for Thalassemia in all over the world, mainly in the Mediterranean areas, Middle East, Indian subcontinent and Southeast Asia [2]. About 500,000 newborn babies per year with thalassemia are suffering with the variety of health problems. In TDT patients, the regular transfusion therapy to maintain hemoglobin level of at least 9 to $10 \mathrm{~g}$ per deciliter for normal requirement of hemoglobin and suppresses ineffective erythropoiesis [3]. These TDT patients may develop clinical manifestations and other severe consequences. The association of iron overload with hepatic damage, renal damage, dyslipidemia, hepatic viral infection and changes in blood parameters with gradual control of malnutrition and communicable disease are under investigation since many years. Majority of TDT patients who earlier died young are surviving long enough to seek medical attention [4,5]. It is observed that different studies have already worked out in Pakistan demonstrating the best approach to minimize these problems and increase awareness among the public to manage it clinically. The aim of present study is to analyze blood parameters of TDT patients at Hyderabad and adjoining areas. 


\section{Materials and methods}

The present study was carried out at Fatimid foundation center Hyderabad from June 2015 to May 2016. Total 71 TDT patients and 84 control subjects (age and gender matched healthy persons having negative personal and family history of any blood disorders) were interviewed through a standard questionnaire to investigate the demographic characteristics, personal information and dietary habits of patients as compared to healthy control subjects. Intravenous $5 \mathrm{~mL}$ whole blood samples of all study participants were also collected to investigate the blood parameters WBC, RBC, HCT, MCV, MCH, MCHC and platelets by using the Sysmex XN-1000 Autoanalyzer (USA). All the reagents used in Autoanalyzer were compatible with Sysmex, and also compatible with optional RU-20 reagent unit. Written informed content was obtained prior to administer the questionnaire. An Institutional Ethical committee approval was also obtained before starting the study.

\section{Participants}

TDT patients were randomly selected from Fatimid foundation center Hyderabad during June 2015 to May 2016. The age range of patients was 5.98 to 15.34 years. Age and gender matched control subjects were also selected having negative personals of family history of any blood disorder.

\section{Blood analysis}

Determination of blood parameters such as RBC, HB level, MCV, MCH, Platelets (Thrombocytes) for WBC, TLC, differential leukocytes count (DLC) were measured, by using the Sysmex XN-1000 Auto analyzer .

\section{Statistical Analysis}

The statistical analysis was done by SPSS (V.22 Inc., Chicago, IL, USA). Values were expressed as mean \pm standard deviation. Student's t-test was performed to compare the blood analysis of TDT patients with control subjects. p-value $<0.05$ was considered as the level of significance in all parameters.

\section{Results and Discussion}

In Table 1 the comparison of blood parameters between TDT patients and control subjects is given which shows that among WBCs, neutrophils have significantly decreased $(\mathrm{p}<0.05)$, whereas, lymphocytes and basophils significantly increased $(\mathrm{p}<0.05)$ in TDT patients compared with control subjects. A significant decrease $(\mathrm{p}<0.05)$ in $\mathrm{RBCs}, \mathrm{MCV}, \mathrm{MCH}, \mathrm{HB}$ and $\mathrm{HCT}$ is observed with a significant increase in MCHC in TDT patients when compared with control subjects. Platelet count is also decreased in TDT patients when compared with control subjects. It has been observed in the present study (Table 1) that neutrophils were significantly decreased while lymphocytes and basophils were significantly increased in TDT patients due to frequent blood transfusion, this is in agreement with the earlier reported method [6] Decreased neutrophils in blood were may be due to acute infection in TDT patients, another reason is deferiprone (chelation therapy) which causes neutropenia and agranulocytosis []]. Furthermore, we found significantly increased lymphocytes and basophiles in TDT patients when compared to healthy control subjects, which indicates an acute infection, specifically a bacterial infection. The RBCs decreased in TDT patients when compared with control subjects similar observation was reported by Galanello in 2010 [8].

No variation in blood parameters of male and female TDT patients could be found on gender wise comparison except monocytes which was significantly decreased in male TDT patients as compared to females. But significant variation was found for comparison of blood parameters between TDT male patient's control subjects (Table 2). RBCs, MCV, MCH, HB and HCT are significantly decreased in male and female TDT patients in comparison to control subjects. Among WBCs significant decrease is observed in neutrophils and monocytes, whereas, a significant increase in lymphocytes and basophils except monocytes is observed in male TDT patients when compared with male control subjects. Decreased Platelets are observed in male TDT patients when compared 
with male control subjects. Neutrophils and platelets are significantly decreased in female TDT patients when compared with female control subjects. An investigator reported that RBCs increased or remained normal in TDT patients. Furthermore, it was reported that $\mathrm{MCV}, \mathrm{MCH}$ and HB remain in normal concentrations in TDT patients, whereas, the revers was found in our study i.e. $\mathrm{MCV}, \mathrm{MCH}$ and $\mathrm{HB}$ reduced in all TDT patients (Table 1) as well as male and female TDT patients (Table 2) in comparison to control subjects [9]. Another study reported that MCH become low in TDT patients and it is in similarity with our findings. It may suggest that frequent blood transfusion changes the hematology of TDT patients.

In Table 3 socio-demographic characteristics of TDT patients and control subjects is presented which revealed that majority of TDT patients are male as compared to females. Highest numbers of TDT Patients are of 5-10 years' age group as compared to other age groups. Majority of TDT patients are migrants and illiterate accompanied by a sedentary lifestyle. We also found that majority of TDT patients are labor followed by shopkeeper by profession with a family history of thalassemia. A research conducted on sociodemographic characteristics concluded that education, life style and profession are fundamental factors in patients with thalassemia [10]. Similar results were observed in present study (Table 3). We observed in our study that majority of TDT patients were male and the same results are reported by Quratulain et al., [11] Whereas other investigators reported that majority of TDT patients were females [12]. Consanguineous marriages are the main reason for spread of thalassemia. Hence, they get married. As male have one $\mathrm{X}$ chromosomes so that is ready affected and female is carrier so ratio of female was increased [13]. We found in Table 3, that age group 5-10 years was commonly affected by thalassemia, whereas, other investigators reported $>15$ years' age group [14]. Present study revealed that majority of TDT patients were migrants and illiterate and were labor by profession, whereas, [15] reported in his study majority of TDT patients as non-migrants and unemployed, whereas, he reported TDT patients as illiterate.
Table 1. Comparison of blood parameters between transfusion dependent thalassemia patients and control subjects.

\begin{tabular}{lccc}
\hline \multicolumn{1}{c}{$\begin{array}{c}\text { Blood } \\
\text { Parameters }\end{array}$} & $\begin{array}{c}\text { TDT patients } \\
\mathbf{N = 7 1}(\boldsymbol{\%})\end{array}$ & $\begin{array}{c}\text { Control subjects } \\
\mathbf{N = 8 4}(\boldsymbol{\%})\end{array}$ & $\begin{array}{c}\text { p-value } \\
(<\mathbf{0 . 0 5})\end{array}$ \\
\hline WBC (TLC) & $8.87 \pm 5.74$ & $9.06 \pm 2.27$ & 0.72 \\
WBC (DLC) & & & \\
Neutrophils & $46.07 \pm 13.09$ & $56.44 \pm 12.45$ & $<0.001$ \\
Lymphocytes & $45.48 \pm 12.80$ & $34.43 \pm 11.91$ & $<0.001$ \\
Monocytes & $5.62 \pm 2.75$ & $6.15 \pm 1.77$ & 0.59 \\
Eosinophils & $2.79 \pm 1.61$ & $2.91 \pm 1.04$ & 0.1 \\
Basophils & $0.31 \pm 0.30$ & $0.30 \pm 0.25$ & $<0.001$ \\
RBC & $2.81 \pm 0.78$ & $4.37 \pm 0.62$ & $<0.001$ \\
Mrythrocytes) & $77.75 \pm 4.96$ & $81.47 \pm 5.77$ & $<0.001$ \\
MCV & $25.07 \pm 2.35$ & $26.40 \pm 2.26$ & 0.002 \\
MCHC & $32.27 \pm 1.27$ & $31.61 \pm 2.59$ & 0.024 \\
HB & $7.16 \pm 2.08$ & $11.56 \pm 1.34$ & $<0.001$ \\
HCT & $22.10 \pm 6.19$ & $36.15 \pm 4.04$ & $<0.001$ \\
Platelets & $252.26 \pm 159.32$ & $368.07 \pm 90.32$ & $<0.001$ \\
(Thrombocytes) & & & \\
\hline
\end{tabular}

TDT $=$ Transfusion dependent thalassemia, $\mathbf{W B C}=$ White blood cells; $\mathbf{T L C}=$ Total leukocyte count; $\mathbf{R B C}=$ Red blood Cells; $\mathbf{M C V}=$ Mean corpuscular value; $\mathbf{M C H}=$ Mean corpuscular hemoglobin; $\mathbf{M C H C}=$ mean corpuscular hemoglobin concentration; $\mathbf{H B}=$ hemoglobin; $\mathbf{H C T}=$ hematocrit.

Table 2. Comparison of blood parameters between transfusion dependent thalassemia male patients and female patients.

\begin{tabular}{|c|c|c|c|}
\hline $\begin{array}{c}\text { Blood } \\
\text { Parameters }\end{array}$ & $\begin{array}{c}\text { Male TDT } \\
\text { patients } \\
\mathrm{N}=71(\%)\end{array}$ & $\begin{array}{c}\text { Female } \\
\text { TDT patients } \\
\text { N=71 }(\%)\end{array}$ & $\begin{array}{l}\text { p-value } \\
(<0.05)\end{array}$ \\
\hline WBC (TLC) & $08.89 \pm 04.42$ & $08.66 \pm 2.76$ & 0.8635880 \\
\hline $\begin{array}{l}\text { RBC } \\
\text { (Erythrocytes) }\end{array}$ & $02.76 \pm 0.69 *$ & $02.94 \pm 0.54^{*}$ & 0.3241389 \\
\hline HB & $07.01 \pm 1.83^{*}$ & $07.45 \pm 1.41^{*}$ & 0.3787420 \\
\hline HCT & $21.60 \pm 5.40^{*}$ & $22.82 \pm 4.30 *$ & 0.4315500 \\
\hline MCV & $77.36 \pm 3.71 *$ & $78.24 \pm 3.87 *$ & 0.4975690 \\
\hline МСH & $25.05 \pm 2.04 *$ & $25.60 \pm 01.53$ & 0.3057620 \\
\hline МСНC & $32.22 \pm 1.18$ & $32.55 \pm 0.81^{*}$ & 0.2433310 \\
\hline \multicolumn{4}{|l|}{ WBC (DLC) } \\
\hline Neutrophils & $45.65 \pm 9.74^{*}$ & $48.16 \pm 9.24 *$ & 0.4180950 \\
\hline Lymphocytes & $46.61 \pm 9.71^{*}$ & $41.91 \pm 8.66$ & 0.1219190 \\
\hline Monocytes & $4.96 \pm 2.16^{*}$ & $06.86 \pm 1.15$ & 0.0028640 \\
\hline Eosinophils & $02.8 \pm 1.12$ & $02.78 \pm 1.64$ & 0.9598570 \\
\hline Basophils & $0.22 \pm 0.21^{*}$ & $0.3 \pm 0.24^{*}$ & 0.1093710 \\
\hline $\begin{array}{l}\text { Platelets } \\
\text { (Thrombocytes) }\end{array}$ & $252.2 \pm 121.1^{*}$ & $263 \pm 119.28 *$ & 0.7893710 \\
\hline \multicolumn{4}{|c|}{$\begin{array}{l}\text { *p<0.05 when compared with control subjects. TDT }=\text { Transfusion } \\
\text { dependent thalassemia WBC }=\text { White blood cells; TLC= Total } \\
\text { leukocytes counts; } \mathbf{R B C}=\text { Red blood Cells; } \mathbf{M C V}=\text { Mean corpuscular } \\
\text { value; } \mathbf{M C H}=\text { Mean corpuscular hemoglobin; } \mathbf{M C H C}=\text { mean } \\
\text { corpuscular hemoglobin concentration; } \mathbf{H B}=\text { hemoglobin; } \\
\text { HCT=hematocrit. }\end{array}$} \\
\hline
\end{tabular}


Table 3. Sociodemographic characteristics of transfusion dependent thalassemia patients and control subjects.

\begin{tabular}{|c|c|c|}
\hline $\begin{array}{l}\text { Sociodemographic } \\
\text { Characteristics }\end{array}$ & $\begin{array}{c}\text { TDT Patients } \\
\mathrm{N}=\mathbf{7 1}(\%)\end{array}$ & $\begin{array}{c}\text { Control } \\
\text { subjects } \\
\mathrm{N}=\mathbf{8 4}(\%)\end{array}$ \\
\hline $\begin{array}{l}\text { Mean age } \\
\text { range (Years) }\end{array}$ & $5.98-15.34$ & $6.38-17.5$ \\
\hline \multicolumn{3}{|l|}{ Gender } \\
\hline Male & 64.78 & 40.47 \\
\hline Female & 35.21 & 59.52 \\
\hline \multicolumn{3}{|l|}{ Age Group } \\
\hline Up to 4 years & 5.63 & 10.71 \\
\hline $5-10$ years & 57.74 & 42.57 \\
\hline $11-15$ years & 15.49 & 21.42 \\
\hline $16-20$ years & 12.67 & 10.71 \\
\hline 21-26 years & 8.45 & 14.28 \\
\hline \multicolumn{3}{|l|}{ Origin } \\
\hline Migrants & 87.32 & 90.47 \\
\hline Non-migrants & 12.67 & 9.52 \\
\hline \multicolumn{3}{|l|}{ Education } \\
\hline Graduates & 1.4 & 35.71 \\
\hline Intermediate & 2.81 & 7.14 \\
\hline Matriculation & 5.63 & 3.75 \\
\hline Middle & 8.45 & 7.14 \\
\hline Primary & 35.21 & 22.61 \\
\hline Illiterate & 46.47 & 23.8 \\
\hline \multicolumn{3}{|l|}{ Life Style } \\
\hline Sedentary & 59.15 & 19.04 \\
\hline Physically Active & 40.84 & 80.95 \\
\hline \multicolumn{3}{|l|}{ Family profession } \\
\hline Labor & 39.42 & 41.66 \\
\hline Govt.Job & 23.94 & 16.66 \\
\hline Land lord & 2.81 & 5.95 \\
\hline Shopkeeper & 33.8 & 35.71 \\
\hline \multicolumn{3}{|c|}{ Family history of thalassemia patients } \\
\hline Yes & 66.19 & 4.76 \\
\hline No & 33.8 & 95.23 \\
\hline
\end{tabular}

TDT $=$ Transfusion dependent thalassemia

In Table 4 dietary habits of TDT patients and control subjects are depicted. Less consumption of white meat is observed in TDT patients as compared, to control subjects. Meat consumption per weak reveals that majority of TDT patients are consuming 1 to 2 times per week followed by 3 to 4 times per week, which is comparatively higher consumption when compared with control subjects. Vegetable consumption, tea intake and milk intake in TDT patients are also higher are TDT Patients in TDT Patients as compared to control subjects. We found that white meat consumption in TDT patients was less than control subjects, as far as frequency of consumption of meat per week is concerned
(Table-4). We found that majority of TDT patients were consuming 1-2 times per week followed by 3-4 times per week, which was comparatively higher consumption than control subjects, [16] also reported that adult thalassemia patients consumed sufficient amount of meat and vegetables which comparable with present study observed that majority of the TDT patients were consuming 5-8 cups per week as compared to control subjects. Higher consumption of tea and milk is reported to be beneficial in TDT patients because it reduces iron absorption as the TDT patients are already iron overloaded due to transfusion [17].

Table 4. Dietary habits of transfusion dependent thalassemia patients and healthy control subjects.

\begin{tabular}{lcc}
\hline $\begin{array}{l}\text { Dietary Habits } \\
\text { Characteristics }\end{array}$ & $\begin{array}{c}\text { TDT Patients } \\
\mathbf{N = 7 1} \\
(\mathbf{\%})\end{array}$ & $\begin{array}{c}\text { Control subjects } \\
\mathbf{N = 8 4} \\
(\mathbf{\%})\end{array}$ \\
\hline White & 57.74 & 84.52 \\
White/Red & 42.25 & 15.47 \\
Meat/weak & & \\
1 to 2 times & 61.97 & 60.71 \\
3 to 4 times & 33.8 & 30.95 \\
5 times & 4.22 & 8.33 \\
Vegetables/week & & \\
Daily & 73.23 & 42.85 \\
Often & 25.35 & 50 \\
Rarely & 1.4 & 7.14 \\
Cup of Tea/ week & & \\
1 to 2 & 7.04 & 19.04 \\
3-4 & 32.39 & 45.23 \\
5-8 & 60.56 & 35.71 \\
Milk/week & & \\
Yes & 66.19 & 29.76 \\
No & 33.8 & 70.23 \\
\hline TDT= Transfusion dependent thalassemia &
\end{tabular}

Milk consumption was also found higher by the TDT patients in comparison to control subjects. The reason is good dietary habits due to counselling of TDT patient by doctors [18].

\section{Conclusion}

It is concluded from the results of present study that transfusion related blood abnormalities are present in TDT patients. They have severe hypochromic microcytic anemia with reduced RBCs and platelets. Age, socioeconomic conditions and education has significant effect on the occurrence of thalassemia. Moreover, positive family history is also a predominant factor. 
Advances in hematopoietic studies have greater improvements in survival and quality of life of TDT patients. Age of survival of TDT patients has changed during last two decades. Socioeconomic conditions and education shows the unawareness for the disease may result in severity of disease. The consanguineous marriages should be avoided to decrease the risk of disease.

\section{Acknowledgement}

The authors would like to thank Fatimid Foundation Thalassemia Center, Hyderabad sampling of thalassemia patients, and to the TDT patients for their cooperation in giving us time and blood samples. Furthermore, also thanks to Department of Zoology, University of Sindh for providing chemicals and materials for Hematology.

\section{References}

1. T. Colley and B. Lee, Trans. Am. Pediatr. Soc., 37 (1925) 29.

http://jamanetwork.com/journals/jamapediatr ics/fullarticle/1174583

2. Chattopadhya and S. Rakter, India Soc., Sci. Med., 63 (2006) 2661.

https://doi.org/10.1016/j.socscimed.2006.06. $\underline{031}$

3. M. Angastiniotis, B. Modell and P. Englezos, Bull World Health Org, 73 (1995) 375. https://www.ncbi.nlm.nih.gov/pmc/articles/P MC2486673/

4. P. Borgna, C. Vergine, G. Lombardo, T. Cappellini, M. D. Cianciulli and P. Maggio, Br. J. Haematol., 124 (2004) 114. https://doi.org/10.1046/j.13652141.2003.04732.x

5. U. Manghrio, S. Baloch, A. R. Royo, M. A. Baloch, S. A. Gujjar and A. I. Memon, IJBPA, 3 (2014) 2342.

https://www.researchgate.net/publication/271 $\underline{073076}$

6. R. Jokhio, Y. Khan, L. Chughtai and A. Mughal, Pak. J. Physiol., 5 (2009) 20. http://www.pps.org.pk/PJP/5-2/Jokhio.pdf
7. R. Galanello and S. Campus, Acta Haematol., 122 (2009) 64. https://doi.org/10.1159/000243800

8. R. Galanello, Orphanet J. Rare. Dis., 5 (2010) 11.

https://ojrd.biomedcentral.com/articles/10.11 86/1750-1172-5-11

9. S. Langlois, J. C. Ford, D. Chitayat, V. A. Désilets and S. A. Geraghty, J. Obst. Gynaecol. Canada, 30 (2008) 950. https://www.ncbi.nlm.nih.gov/pubmed/1903 $\underline{8079}$

10. H. Maheen, F. Malik, B. Siddique and A. Qidwai, Pak. J. Genet. Couns., 1 (2015) 7. https://www.ncbi.nlm.nih.gov/pubmed/2584 $\underline{3562}$

11. L. A. Qurat-ul-Ain, M. Hassan, S. M. Rana and F. Jabeen, Pak. J. Zool, 43 (2011) 36. http://zsp.com.pk/29-36\%20(6)\%20PJZ-1009.pdf

12. Y. Yousafzai, M. Khan and S. Raziq, J Ayub Med Coll Abbottabad, 22 (2010). 84. https://www.ncbi.nlm.nih.gov/pubmed/ $\underline{22455269}$

13. D. Loesch and D. A. Hay, J. Med. Genet. Jun., 25 (1988) 407. https://www.ncbi.nlm.nih.gov/pubmed/3398 $\underline{009}$

14. C. Borgna-Pignatti, Haematologica, 95, (2010) 345 . doi:10.3324/haematol.2009.017228

15. K. Ishfaq, T. Ahmad, S. Naeem, B. Ali and J. Zainab, IMJ., 8 (2016) 79. https://www.researchgate.net/ publication/303931383

16. S. Srichairatanakool and S. Fucharoen, In. Tech., 10 (2014) 572. doi: $10.5772 / 57372$

17. Ziegler. Nutr. Rev., 69 (2011) 37. doi: 10.1111/j.1753-4887.2011.00431.x.

18. E. B. Fung, Y. Xu, F. Trachtenberg, I. Odame, J. L. Kwiatkowski, E. J. Neufeld and A. A. Thompson," J. Acad Nutr Diet., 112 (2012) 980. doi:10.1016/j.jand.2012.01.017. 